Article received on $17^{\text {th }}$ Jun 2014

Article accepted on $29^{\text {th }}$ Jun 2014

UDC: 792.07:929 Грол М.

\author{
Sanela Nikolić* \\ University of Arts in Belgrade \\ Faculty of Music \\ Department of Musicology
}

\title{
THE OPERA QUESTION IN BELGRADE AS ‘STAGED’ BY MILAN GROL ${ }^{1}$
}

\begin{abstract}
Writer, politician, and dramaturge Milan Grol can be credited with the most important contribution of an individual to the modernization of the National Theatre in Belgrade. A reformer, legislator, organizer of international theatre cooperation, and manager of the National Theatre, he also played a key role in defining 'the opera question' in Belgrade during the first two decades of the $20^{\text {th }}$ century. Commendable as his activities were in terms of the institutional organization and advancement of South Slavic theatres, it must also be noted that owing to his unfavourable attitude towards the performance of opera at the National Theatre, the development of its opera ensemble and establishment of an artistically worthy opera repertoire at this theatre came to a halt in the first decade of the $20^{\text {th }}$ century. Grol's views about opera at the National Theatre reflect a striking ambivalence in his dual professional personality of a politician and writer. As a member of the Independent Radical Party, he supported a pro-European orientation and cultural elitism, which were meant to serve democratic and educational goals. However, when it came to the question of opera at the National Theatre, he abandoned his guiding principles devoted to modern European standards. Grol thus reinterpreted his firm political basis in the field of partisan clashes and appropriated the power to regulate the repertoire of the National Theatre; yet, for all that, he never gave up his primary vocation of a writer and
\end{abstract}

\footnotetext{
* Author contact information: saneladnikolic@yahoo.com.

1 This study was realized under the auspices of the scholarly project Identiteti srpske muzike u svetskom kulturnom kontekstu [Identities of Serbian Music in a Global Cultural Context] at the Department of Musicology of the Faculty of Music in Belgrade, supported by the Ministry of Education and Science, under Reg. No. 177019.
} 
dramaturge, who saw the presentation of the highest aesthetic achievements of national and European literature as the sole purpose of the institution he managed.

Key words: Milan Grol, National Theatre in Belgrade, modernization, opera question, operetta, Srpski književni glasnik, National Theatre Act

During the first two decades of the $20^{\text {th }}$ century, the presence of a foreign and domestic operatic repertoire at the National Theatre and establishing of a separate opera house were at the centre of some of the most heated controversies in the musical life of Belgrade. Divergent opinions as to what kind of art the National Theatre was supposed to promote - literature or music, drama or opera - were elicited by the original conception of national theatres in the Balkans as drama theatres, "za čiju su se estetiku borile generacije intelektualaca, uglavnom književnika, imajući prvenstveno u vidu vaspitnu ulogu dramskog teatra" ["whose aesthetics was fought for by generations of intellectuals, mostly writers, who saw the edification of the nation as the primary goal of drama theatre" $].^{2}$ During the first decade of the $20^{\text {th }}$ century, members of several National Theatre administrations incorporated into their political struggles polemics about whether the Theatre's repertoire should focus on drama only, or both on drama and music as well. These polemics permeated attempts at an institutional reform of South Slavic theatres by way a systemic legislative regulating of the goals and domains of their activities. Concerning the status of the Belgrade National Theatre, this institutional reform was seen as a possible solution to the ongoing crisis, with which almost all Theatre administrations had to cope around the turn of the century. The credit for being the most important individual contributor to such endeavours goes to the writer, politician, and dramaturge Milan Grol (1876-1952). As a result of Grol's intensive efforts as a theatre reformer, legislator, organizer of international cooperation, dramaturge (1903-1906) and general manager of the National Theatre (1909-1924), ${ }^{3}$

\footnotetext{
2 Nadežda Mosusova, "Srpska muzička scena (125 godina Narodnog pozorišta)" ["The Serbian Musical Stage (The 125th Anniversary of the National Theatre"], in: Nadežda Mosusova (ed.), Srpska muzička scena [The Serbian Music Stage], Belgrade, Muzikološki institut - Srpska akademija nauka i umetnosti, 1995, 9.

3 In March 1910, due to a fundamental disagreement with the Minister of Education, Grol submitted his resignation. Milan Predić and members of the Literary and Artistic Board (Dragomir Janković, Jovan Skerlić, and Stevan Mokranjac) did the same. The management of the Theatre was entrusted to Milorad Gavrilović, who was to remain in office for less than a year, because on 1 January 1911 Grol was reinstated and remained in that post until 28 February 1924, with a break during the First World War when the National Theatre and all other cultural institutions were closed. See Zoran T. Jovanović, "Milan Grol - pozorišni reformator" ["Milan Grol - A Theatre Reformer"], Zbornik Matice srpske za scenske umetnosti i muziku, 28/29, 2002, 117.
} 
Nikolić, S.: The Opera Question In Belgrade As 'Staged'By Milan Grol (107-122)

the Theatres Act was passed in 1911; the School of Acting was established at the Theatre in 1909; the School of Acting and Ballet became an independent educational institution in 1921; many actors and directors, as well as singers and choirmasters after the First World War ${ }^{4}$ were sent abroad for education. The founding of the Alliance of Slavic Theatres and the organization of its first congress in 1923 in Belgrade was also his work and so was the publishing of the Slavic Theatre Review with the aim of presenting the art of Slavic theatres in Europe. ${ }^{5}$ The present paper argues that owing to such diverse activities, Milan Grol was a key figure in defining the 'opera question' in Serbia. Commendable as his multifarious activities were in terms of the institutional organization and advancement of South Slavic theatres, it must also be noted that owing to his unfavourable attitude towards the performance of opera at the National Theatre, the development of its opera ensemble and the process of establishing an artistically worthy operatic repertoire at this theatre came to a halt in the first decade of the $20^{\text {th }}$ century.

His stance on the question of opera at the National Theatre was a symptom of his political views, which also shaped his position regarding institutional reform at the Theatre. As a matter of fact, the opera question was part and parcel of the political turmoil of the first half of the $20^{\text {th }}$ century and a reflection of the clashes between the politics of the 'old' radicals and a new generation of the so-called Independent Radicals. The latter group mainly comprised intellectuals educated in France and Germany, such as Grol himself. The Independent Radicals' agenda placed considerable emphasis on raising the cultural level of the population. This new generation of radicals entered the political scene around 1905, claiming that education received far too little attention in this country, while civil virtues, vital for a democratic society, were neglected. "Jedan od glavnih ideologa samostalaca Jovan Skerlić naglašavao je da 'demokratije ne može biti bez elite, jer ne može biti bez genija, nauke i vrline"" ["One of the Independents' chief ideologues, Jovan Skerlić argued that 'there can be no democracy without an elite, for we cannot do without genius, without science and virtue"']. ${ }^{6}$ A bourgeois culture fashioned after Western European models and conceived as an elitist form of culture was expected to establish a lasting rap-

\footnotetext{
4 Milan Grol, "Glumačka škola. Pristupno predavanje i program" ["The School of Acting. Inaugural Lecture and Curriculum”], Srpski književni glasnik, 1909, 23/12, 944-951.

5 Cf. Dragana Čolić Biljanovski, "Saradnja u oblasti pozorišne umetnosti početkom XX veka" ["Cooperation in the Domain of Theatre Art at the Beginning of the $20^{\text {th }}$ Century"], Zbornik Matice srpske za scenske umetnosti i muziku, 2008, 39, 65.

6 Dušan T. Bataković, "Francuski uticaji u Srbiji 1835-1914. Četiri generacije 'Parizlija"” ["French Influences in Serbia, 1835-1914. Four Generations of 'Parisians"'], Zbornik Matice srpske za istoriju, 1997, 56, 91-92.
} 
port with the masses; along with democratization, this was meant to achieve the edification of the people. Accordingly, the repertoire of the National Theatre was conceived as a presentation of the highest aesthetic achievements of European and especially national culture, with educational goals in mind. This meant that no concessions to a lower taste should be made by performing 'light', entertaining plays, easily accessible to wider audiences. In June 1902, upon Grol's return after two years of studies in Paris, the Minister of Education appointed him as member and coordinator of the committee tasked with drafting a law on theatres. After his second stay in France in 1905, Grol spoke about theatre as a fact of education that could indirectly influence the process of democratization and the popularization of theatre in general. ${ }^{7}$ Adhering to the political stance of the Independent Radicals that national cultural development and democratization ought to proceed in accordance with the model of culture as enlightenment, Grol strove to implement the best European - French and German - cultural practices in the South Slavic theatre system, by way of improvements in legislation, repertoire reforms, professionalizing stage direction, cooperating with foreign artists and educating theatre personnel.

Despite all of these positive efforts, Grol's position regarding opera reflects an utterly negative, radically critical attitude, a practical consequence of which was its tendency to bring the opera life at the National Theatre to a complete stop. The reasons for such moves on Grol's part should be sought in two tendencies that were current at that time. One was based on the need to oppose the repertoire policy of the opposing political factions that had dominated the preceding Theatre administration. It was imperative to criticize that policy if the Independent Radicals were to prevail. The second aspect of the problem was of a professional and artistic nature: as a writer and dramaturge, Grol had reached the conclusion that the drama branch of the National Theatre was in a serious crisis and that opera, with its ever increasing audience, would only exacerbate that crisis. This was a latent but persistent concern in Grol's texts on operetta and opera published in Srpski književni glasnik between 1904 and 1908. ${ }^{8}$ It is as if Grol had refused to acknowledge the popularity of opera in Belgrade and the willingness of the audience to accept the latest achievements in operatic performance. The

\footnotetext{
${ }^{7}$ On his journey back from France, Grol spent time in Munich and Vienna in order to study the organization and legal regulations of German and Austrian state theatres. See Zoran T. Jovanović, op. cit., 108-109.

${ }^{8}$ The texts in question are "Pitanje o opereti u Narodnom pozorištu" ["The Question of Operetta at the National Theatre"], "Opera u Narodnom pozorištu" ["Opera at the National Theatre"], "Narodno pozorište" ["National Theatre"] (three instalments), published in Srpski književni glasnik, the leading professional literary journal of the time, in 1904, 1906, and 1908, respectively.
} 
immaturity of the audience, inadequacy of the performers employed at the National Theatre, and the entertaining character of opera were his chief arguments against accepting an operatic repertoire and advancing the genre of opera, which had been initiated by previous administrations and fully implemented between 1906 and $1909 .{ }^{9}$ It is precisely owing to Grol's activities that

...deo istorijata Narodnog pozorišta u Beogradu u deceniji pred Prvi svetski rat upućuje na diskontinuirane procese profesionalizacije i modernizacije muzičke grane i njenog repertoara. Reč je o naglim promenama koje su se ogledale u kratkotrajnom unapređenju muzičkog ansambla i izvođenju operskih dela (1906-1909), potom u poništavanju tih napora i rezultata i povratku u stare repertoarske okvire, a zatim o radu ispočetka i novom pokušaju uspostavljanja opere (1913-1914). [...part of the history of the National Theatre in Belgrade in the decade preceding World War I suggests a discontinuity in the process of the professionalization and modernization of the Theatre's musical branch and its repertoire. It was the result of abrupt changes occurring at that time, reflected in short-lived improvements to the music ensemble and performance of operatic works (1906-1909), followed by an undoing of all of those efforts and results, returning to old repertoire frameworks, and then a new beginning and a new attempt to establish opera (1913-1914)]. ${ }^{10}$

9 "Podaci i statistike vezani za deceniju pre Prvog svetskog rata mogu jasno da upute na međusobnu koliziju programskih ciljeva pozorišnih Uprava. Naime, u periodu od 1906. do 1909, kada je Uprava Nikole Petrovića inicirala, a Uprava Mihaila Markovića i Riste Odavića sprovela ideju muzičkog programa Pozorišta, izvođena su dela standardnog operskog repertoara Kavalerija rustikana, Pajaci i Prodana nevesta, na čelu sa dirigentom Dragutinom Pokornim. Zbog realizacije tih projekata i težnje da se uspostavi kontinuitet $u$ negovanju opere, pristupilo se unapređenju hora i angažovanju određenog broja profesionalnih solista. Pojačan je i orkestar, postavši najveće instrumentalno telo u prestonici, pa je Uprava smatrala da bi on trebalo da ostane čak i u slučaju odustajanja od opere ..." ["The data and statistics related to the decade before World War I clearly indicate a collision between programming ideas of different Theatre administrations. Namely, between 1906 and 1909, under the administration of Nikola Petrović, the musical programme was initiated, and under Risto Odavić, put into effect, thus works from standard operatic repertoire, such as Cavalleria rusticana, Pagliacci, and The Bartered Bride were performed, conducted by Dragutin Pokorni. To enable the realization of these projects and establish continuity in the performance of opera, the choir was enhanced with a number of professional singers. The orchestra was also reinforced to become the largest performing body in the capital, so the management believed it should remain in place even if the opera project were abandoned ..."]; Biljana Milanović, "Politika u kontekstu 'operskog pitanja' u Narodnom pozorištu pred Prvi svetski rat" ["Politics in the Context of the 'Opera Question' at the National Theatre before the First World War"], Muzikologija, 2012, 12, 40.

${ }^{10}$ Ibid., 37. 
With Grol's appointment as the general manager, all previous efforts were abandoned, the music ensemble significantly reduced, and the performance of opera stopped. ${ }^{11}$

Given that the National Theatre functioned as a spoken-drama theatre from the very beginning, Grol's activities only resulted in a more clearly profiled dramatic sphere, which guided Grol's decisions to allow certain musical works as a concession serving to entertain the audience. As a man of letters, he gave preference to drama and, accordingly, strove for a continual improvement and modernization of the Theatre's drama branch, at the expense of its musical branch.

Osnovni problemi koje je Grol od početka nastojao da reši nalazili su se na samom polju negovanja dramskog repertoara, u poznatoj, višegodišnjoj pozorišnoj krizi, koja je od kraja 19. veka pa nadalje bila obeležena slabim interesovanjem publike za dramu i tragediju, a posebno za nacionalno-istorijska scenska ostvarenja domaćih pisaca. [The principal problems that Grol was trying to solve from the beginning resided in the field of the drama repertoire and related to the well-known and longstanding crisis dating back to the end of the $19^{\text {th }}$ century. The crisis concerned a lack of public interest for drama and tragedy, particularly for national-historic stage works by domestic authors]..$^{12}$

In his text "Pitanje o opereti u Narodnom pozorištu" ["The Question of Operetta at the National Theatre"], published in 1904 in Službeni glasnik, Grol gave a description of the public's prevailing attitude of indifference towards literary achievements, precisely blaming the operatic repertoire for that. The middle-class audience was much more attracted to that entertaining musical stage genre, which diminished the number of those interested in aesthetically relevant dramatic works. A repertoire featuring operatic works could only exacerbate this division in favour of musical as opposed to literary genres.

11 The première and four subsequent performances of Smetana's The Bartered Bride took place at the beginning of 1909. Already in February, following Grol's reinstatement as general manager, the opera was taken off the repertoire. The next operatic première at the National Theatre was not held until 1911 (six months after the great success of the Croatian Opera in Belgrade). It was an unsuccessful performance of Mozart's Bastien und Bastienne. Opera was revived at the National Theatre with great success and a large number of premières during the season of 1913-1914, when Stanislav Binički became the conductor. See Slobodan Turlakov, Istorija opere i baleta Narodnog pozorišta u Beogradu [The History of the Opera and Ballet of the National Theatre in Belgrade], Vol. 1, Belgrade, Čigoja štampa, 2005, 58-59; Roksanda Pejović, "Repertoar Opere i Baleta Narodnog pozorišta (18821941)" ["The Opera and Ballet Repertoire of the National Theatre (1882-1941)"], in: Opera $i$ Balet Narodnog pozorišta u Beogradu [Opera and Ballet in the National Theatre in Belgrade], Belgrade, publisher unknown, 1996, 306.

12 Biljana Milanović, op. cit., 49. 
In his text from 1904, Grol emphasized that the National Theatre's paramount function was to participate in the construction of a national identity.

Nesumnjivo je - i prema zakonu, i prema namerama njegovog prvog dobrotvora, $\mathrm{i}$ po ulozi koju ova državna i nacionalna ustanova ima u literaturi, u umetnosti, u narodnom obrazovanju, u opštoj nacionalnoj kulturi - da u Narodnom pozorištu nije mesto ni austrijskim valcerima, ni kaplarskim galanterijama 'Jedne japanske čajdžinice'. Taj razlog narodnog obraza u ovom pitanju toliko je očigledan i neosporan da - hvala Bogu - pored sveg današnjeg darmara u javnom životu, nijedan čovek od imena, nijedan list, nema smelosti da ga porekne [There is no doubt - according to the law, according to the intention of its first benefactor, and indeed according to the role that this national and state institution plays in literature, art, national enlightenment, in national culture in general - that the National Theatre has no place for Austrian waltzes, or for such petty gallantries such as 'A Japanese Tearoom'. In this matter, this motive of national honour is so evident and beyond any doubt that thank God - for all the mess in public life, no decent man and no newspaper could deny it $].{ }^{13}$

Grol found justification for the presence of operettas alongside "serious" dramatic repertoire in the practical side of repertoire policy, that is, in striving to bind the audience to the house. He even concluded that, by the onset of the $20^{\text {th }}$ century, operetta had virtually 'killed' national song plays.

Dok još ne bude stvorena stalna publika, dok još bude ovakve heterogenosti u njoj, dok drama ne bude toliko jaka da sama bude dovoljna privlačnost - misli se potrebno je truditi se da se publika veže za kuću... ["Until there is a permanent audience, for as long as there is this much heterogeneity in it, and until drama has become strong enough to constitute an attraction in itself - so it is believed - it is necessary to strive to tie the audience to the house...]. ${ }^{14}$

Grol, however, proceeds to argue that a repertoire featuring both high dramatic achievements and worthless foreign operettas could not create a permanent theatre audience, precisely the kind of audience that ought to form the core of a theatre and could appreciate every theatrical achievement.

Sa ovim u vezi može se govoriti o zamerkama koje se čine drami. Ako se nalazi da drama danas ni po glumačkoj veštini ni po inscenaciji, po kostimu i dekoraciji ne može da zadovolji beogradsku publiku - a o njenom prefinjenom ukusu moglo bi se dosta govoriti - onda je još apsurdnije stvarati stalnu publiku šarenim repertoarom - podizati dramu davanjem opereta. Jer mora se priznati, teško je naći neobičnijeg načina za negovanje ukusa za dramu i školovanje dramskih glumaca - od mazurki u

13 Milan Grol, "Pitanje o opereti u Narodnom pozorištu" ["The Question of Operetta at the National Theatre"], Srpski književni glasnik, 1904, 11/75, 302.

14 Ibid., 302. 
'Đaku prosjaku' i baleta u 'Gejši'. [In this context one might speak of objections raised concerning spoken drama. If one maintains that spoken drama today cannot satisfy the Belgrade audience either in terms of its acting skills and staging, costumes and stage sets - and its refined taste could be discussed at length - it is yet more absurd to try to create a permanent audience by a motley repertoire - to elevate drama by performing operettas. For one must admit, there could hardly be a more unusual way of cultivating a taste for drama and for educating dramatic actors than by playing the mazurkas from 'The Beggar Student' and the ballet from 'The Geisha'.] ${ }^{15}$

Grol believed that acquiring a mass audience and meeting the budget with soldout operetta performances could not justify so many operettas on the stage of the National Theatre, given that drama itself had generated substantial revenue even many years before, when operetta had not even existed at this institution.

Istina je da opereta dolazi u red najposećenijih komada: to nije nimalo čudnovato kad se zna da je to žanr lak i dopadljiv, svojom melodičnom muzikom, svojim sceničnim šarenilom, svojom panoramom žena i kostima, i kad se zna kako se ona danas daje a kako drama, ali ta dobro posećena opereta (kojoj bi to bio jedini - za nuždu - razlog da se trpi u subvencionisanom Narodnom pozorištu ) - nema ni izbliza moć koja joj se pripisuje. Njeni najvatreniji branioci išli su čak dotle da kažu: da opereta izdržava dramu. Drama je međutim u Narodnom pozorištu živela trideset godina bez 'Ptičara' i 'Gejše' i - sme se reći - nije joj bilo nimalo gore no danas. Treba samo pogledati prihode poslednjih deset godina, srednje prihode drame za se i srednje prihode sa operetom pa da se vidi kako je cela ta graja naduvana i koliko se sva ta muka, šteta i sramota isplaćuje. [It is true that operetta ranks among the best attended performances: this is by no means strange if one takes into account that it is a light and likeable genre, with its melodious music, variegated stage setting, panorama of women and costumes, as well as the difference in performance between operetta and spoken drama; and yet, this well-attended operetta (which would be - out of necessity - the only excuse for tolerating it at the state-funded National Theatre) - is far from possessing the powers ascribed to it. Its most ardent champions went as far as to say that operetta was financially providing for spoken drama. Spoken drama, however, thrived at the National Theatre for almost thirty years without 'The Bird-Catcher' and 'The Geisha' and - we have every right to claim - it fared none the worse for that. Just look at the revenues of the last ten years, average revenues of drama alone and those with operetta included: it is plain that all of this hullabaloo is much inflated and that all this trouble, harm, and disgrace is hardly worth it at all]. ${ }^{16}$

In conclusion, Grol points out:

Još jednom: Nije opereti mesto u Narodnom pozorištu, ni po imenu koje ono nosi, ni po ulozi koje ono treba da igra u narodnom životu, kao što je u njega ne dovodi

15 Ibid., 304-305.

16 Ibid., 308-309. 
nikakva nužda: nije to put ni da se stvori stalna publika, ni da se podigne drama, ni da se ova ustanova obezbedi finansijski. Opereta se u Narodnom pozorištu još najviše - može trepeti privremeno, onoliko koliko je se do danas zateklo, i dok je publika bude trpela ovakvu kakva je, sa domaćim pevačkim snagama, sa istim horom i orkestrom što se u našim skromnim prilikama daje 'Đidi', 'Koštani' i 'Suđajama'. Obraćati joj pažnju koja se do danas u ovoj kući još nikad nije ni upola obraćala Šekspiru ni Molijeru ni narodnim komadima, traćiti vreme i energiju najboljih glumaca na učenje kupleta i baleta, usiljavati se da se 'Ptičar' i 'Đak prosjak' održe u nekom neobjašnjivom sjaju pored 'Hamleta' i 'Pere Segedinca' u dronjcima - besmisleno je, sramota je, i zločin prema ovoj ustanovi. [Once again: operetta has no place at the National Theatre: neither the Theatre's name, nor the role it ought to play in the life of the nation justify its existence; nor is it a proper way to create a regular audience, nor to elevate drama, nor to provide for this institution financially. Operetta at the National Theatre can be but tolerated; temporarily at that, and to an extent not greater than it is at present, only for so long as the public puts up with it, with its domestic singers, with the same choir and orchestra that our modest circumstances allow for 'Đido', 'Koštana', and 'Suđaje'. To lavish on it half the attention that has ever been lavished on Shakespeare or Molière, to waste the time and energy of our best actors on learning couplets and ballets, to invest so much effort in sustaining 'The Bird-Catcher' and 'The Beggar Student' in some inexplicable glory alongside 'Hamlet' and 'Pera Segedinac', which are in tatters - is meaningless, shameful, and a crime against this institution. $]^{17}$

It is evident that such explicit, radically critical attitudes resulted from Grol's political orientation as an Independent Radical, which meant, on the one hand, the promotion of cultural elitism with an educational function, and on the other, the realization that the original conception of the National Theatre as a national drama theatre was a failure. Two years later, in 1906, provoked by the introduction of opera into the permanent repertoire of the National Theatre, Grol wrote an article for Srpski književni glasnik in which he expressed, almost panicking, his view that its opera repertoire would be the last straw in the destruction of the National Theatre as an institution whose aim was to cultivate literary creativity of a high aesthetic value.

Iz jednog ili drugih uzroka ili oba zajedno, zbog slabosti u predstavljačkom osoblju ili u režiji, zbog podvojenosti u ovako jednoj maloj publici, i zbog toliko opsežnog i mnogostrukog programa što ima da podmiri jedno jedino prestoničko, državno i nacionalno pozorište, repertoar Narodnog Pozorišta predstavlja danas jednu nesređenu, haotičnu masu komada koji se vrlo neobuzdano naslanjaju na publiku, koji se iznose na pozornicu bez ikakvog reda i veze, i kojima je danas teže no ikad postaviti jedan dosledan program i jedan pouzdan kompromis. ... Koliko uviđa sve ove potrebe i nevolje koliko ozbiljno oseća sav zamašaj ovih teških i neodložnih

17 Ibid., 310. 
pitanja jedna pozorišna uprava koja u svem tom pozorišnom haosu - osniva operu! Operu, u današnjem beogradskom Narodnom Pozorištu! Iz kakvih potreba, s kakvim razlozima, na kojoj osnovi, s kakvim izgledima, s koliko ozbiljnosti? Operu bez publike, operu bez materijalnih sredstava, operu bez i jednog pevača za operu! ... Prelazeći preko svih tih obzira i skrupula, zanemarujući najglavnija i najneodložnija pitanja programa, napretka i opstanka, u svem današnjem pozorišnom dar-maru, današnja pozorišna uprava povratila je i operetu, dovela je strane pevače i zavodi i - operu. Sad je haos potpun. [For one of two reasons, or both; because of the weakness either of the performing cast or the staging, because of divisions in the audience itself, small as it is, and because of so extensive and diverse a programme required from the only national theatre in the capital, the repertoire of the National Theatre today represents a chaotic, disorderly mass of plays unleashed on the audience in a completely unrestrained manner; plays brought to the stage without any order or relevance, with which today, more than ever, it is difficult to establish a consistent programme or a reliable compromise. ... How aware is the theatre administration of all those needs and afflictions, how seriously does it take the full extent of these difficult and pressing questions, when amidst all this chaos it establishes an opera! An opera in today's National Theatre! For what need, for what reason, on what basis, with what kind of prospects, how seriously? An opera without an audience, an opera without the financial means, an opera without a single opera singer! ... Ignoring all considerations and scruples, disregarding the paramount and urgent questions of programming, progress, and indeed survival, amidst all this turmoil, the present administration has even revived operetta, brought foreign singers, and now it introduces - opera! The chaos is now complete. $]^{18}$

Two years later, in 1908, Grol published an article in which he again, only in a more sanguine tone, addressed the poor material conditions prevailing at the National Theatre, which in the meantime had further deteriorated. ${ }^{19}$ It is particularly interesting that this time Grol blamed operetta entirely for the degradation of all segments of the Theatre's activities, without mentioning opera.

Najzad, na najgrešniju slabost oba režima za poslednje dve godine, na raspikućno negovanje operete, čak i posle osvedočenog iskustva da ona - pored toga što rasipa snagu i pažnju, što skreće u stranu ceo rad, što demoralizuje ukus, što sramoti nacionalno pozorište - jede i ono malo s mukom stečene i isprošene pomoći srpskoj pozorišnoj umetnosti. Za rasipanje na ovoj strani ne može biti nikakvih opravdanja, i mi se nikada nećemo ustručavati da podvučemo sav greh za ovaj moralni i materijalni zločin. [Finally, the most sinful weakness of both regimes of the past two years, namely, the extravagance of cultivating operetta despite the confirmed experience

${ }_{18}$ Milan Grol, "Opera u Narodnom pozorištu" ["Opera at the National Theatre"], Srpski književni glasnik, 1906, 17/141, 859, 860-861.

19 Milan Grol, „Narodno pozorište” [“The National Theatre”], Srpski književni glasnik, $1908,21 / 188,753-756$. 
that it not only dissipates energy and attention, diverts all our efforts, demoralizes taste, brings disgrace to our national theatre, but also literally consumes whatever little financial support the Serbian theatrical art has struggled to procure. On no account may this extravagance be justified and we will never hesitate to point out the iniquity of this moral and material crime. $]^{20}$

In 1908 Grol could no longer search for arguments against previous administrations in the failure of the operatic repertoire, which by that time had well established itself due to the need for opera that was widely felt in Belgrade and attracted large audiences. This is why this time he

...poslužio oprobanom strategijom svoje partije, koja se u periodu 'skupštinske opstrukcije' do aprila 1908. najčešće bavila budžetskim pitanjima vladajućih radikala, preteći im i ustavnom krizom. Tekst objavljuje krajem iste godine, kada je njegova stranka činila deo privremene koalicione vlade upravo s radikalskim oponentima, što navodi na pomisao da je već tada računao na pregrupisavanje moći i u samom Pozorištu. [...resorted to the tried and tested strategy of his party, which was at this time, during its 'parliamentary obstruction' until April 1908, chiefly preoccupied with the budgetary issues of the ruling Radicals, threatening them with a constitutional crisis. The text was published towards the end of that year, when his party was part of a provisional coalition government with their Radical opponents, which suggests that he was already counting on a redistribution of power at the Theatre itself. $]^{21}$

Grol and his associates' persistent efforts to prevent the National Theatre from becoming an institution devoted both to literary creativity and the genre of opera are also in a peculiar way confirmed by their reactions to the endeavours of Žarko Savić to establish a separate opera house in Belgrade. Savić's original idea was that opera as a separate institution be launched as part of the National Theatre. In 1906, the Štampa daily carried an interview with Savić, in which he described his intention to found an opera at the National Theatre. "Najpre, zgradu već imamo, to je Narodno pozorište koje nad mnogim pozorištima sveta ima tu dobru stranu što je akustično. Opera bi bila gajena u istoj zgradi, u kojoj se danas gaji drama" ["First of all, the building we already have, the National Theatre, which has the advantage over many other theatres in the world in that its acoustics is very good. Opera would live in the same building where drama lives today"]. ${ }^{22}$ Without directly naming Savić, but referring to potential wishes

\footnotetext{
${ }^{20}$ Milan Grol, „Narodno pozorište” [“The National Theatre”], Srpski književni glasnik, 1908, 21/190, 919-920.

${ }^{21}$ Biljana Milanović, op. cit., 46.

22 Anonymous, "Opera u Beogradu" ["Opera in Belgrade"], Štampa, 8 June 1906, 1, quoted in: Slobodan Turlakov, "Opera na Bulevaru Žarka Savića” [“Žarko Savić's Opera in the Boulevard”], in: Iz muzičke prošlosti Beograda [From Belgrade’s Musical Past], Belgrade, published by the author, 2002, 131.
} 
to establish other forms of theatre in our milieu, Dragomir Janković, a close associate of Grol, ${ }^{23}$ pronounced the following judgement in a 1907 issue of Srpski književni glasnik:

Osim domaće muzike, za koje će snaga biti dovoljno, druga muzika teško da će moći u okvir NP. Uzimam tu koncerte koji se ne isplaćuju. Ako se vremenom nađe dosta njih koji zažele neku drugu vrstu - pozorišnu ili muzičku - stvaraju se novi teatri te vrste. Ali, to je stvar privatne inicijative, konkurencije i publike, koja hoće ta zadovoljstva. [Besides domestic music, for which we do have sufficient resources, other music is not very likely to exist at the National Theatre. Here I mean concerts that do not make money. If over time there should appear a large number of those interested in other types of performance, either theatre or music, new theatres of an appropriate type should be created. But that would be a matter of private initiative, competition, and the audience demanding such pleasures. $]^{24}$

Savić realized his idea only in December 1909, when the King's secretary was precisely Dragomir Janković. It is therefore not surprising that Savić's Opera on the Boulevard functioned for a full 13 months without any government subsidies. $^{25}$

The constellation of relationships between the musical and drama segments of the National Theatre that Grol supported and publicly promoted in Srpski književni glasnik from 1904, and then practically realized by abolishing opera in 1909 when he took over as general manager, was formally confirmed by the National Theatre Act of May 1911, the first piece of legislation regulating that institution, and the decree that accompanied it the same month. In order to accelerate the passing of the Act, Grol petitioned the Minster of Education with a feasibility study of a comprehensive reform of the National Theatre. By arguing that it was necessary "utvrđivanje izvesnih principa za kretanje repertoara, i u tome duhu, pročišćenje repertoara (književno i jezičko)" ["to define certain principles in the creation of the repertoire and in that spirit to cleanse the repertoire (literarily and linguistically)"']26 Grol once again confirmed that he viewed the National Theatre as an institution exclusively dedicated to spoken drama. Accordingly, the Act was shaped in such a way as to ignore the fact that for a long time there had been a musical stage at the National Theatre, requiring a special

${ }^{23}$ Likewise a former manager of the National Theatre, whose term coincided with Grol's engagement as dramaturge (1903-1906).

${ }^{24}$ Dragomir Janković, "Povećane subvencije - repertoar - igra. I" [Increased Subsidies The Repertoire - Performance. I], Srpski književni glasnik, 1907, 19/156, 148.

${ }^{25}$ Cf. Slobodan Turlakov, op. cit., 140.

${ }^{26}$ Dr Gavrilo Kovijanić, "Građa Arhiva Srbije o Narodnom pozorištu u Beogradu 18351914" ["Sources on the National Theatre at the Archives of Serbia, 1835-1914"], Belgrade, 1971, 753, quoted in: Zoran T. Jovanović, op. cit., 111. 
ensemble for its activities. The foremost intention of the Act was to regulate the division of administrative power, the evaluation of actors for the purpose of calculating their salaries, and to emphasize the role of stage management as an independent activity, after the model of European theatres. The Literaryartistic Board was abolished and full authority and responsibility transferred to the manager; contracts between the management and actors and a system of fees per performance were introduced as a safeguard against excessive bureaucracy. The dramaturge's role was taken over by the secretary who was the chief aide to the manager in administrative relations and in charge of all artistic affairs. ${ }^{27}$ The status of music at the Theatre, however, was only roughly outlined and at that, not even in the main text of the Act but in an accompanying decree issued by then Minister of Education Jaša Prodanović with the intention to emphasize the aims and tasks of the Theatre. Thus, the principal task of this cultural institution was, according to the decree, "neguje pozorišnu umetnost uopšte" ["to cultivate theatre art in general"] and to "neguje nacionalnu kulturu i ideju" ["cultivate national culture and the national idea"], as well as to "neguje sve grane nacionalne umetnosti, u vezi sa svojim glavnim zadatkom naročito umetnost muzičku i dekorativnu" ["cultivate all branches of national art in connection with its principal task, especially music and decorative art"]. ${ }^{28}$ Regarding its musical programme, Prodanović underlined that the National Theatre should primarily focus on "srpsku i hrvatsku muziku i srpske i hrvatske muzičare, zatim na slovensku i stranu muziku, u granicama sredstava, pravilne srazmere s glavnim zadatkom Narodnog pozorišta, i na dobar uticaj na nacionalnu muziku" ["Serbian and Croatian music and Serbian and Croatian musicians, then also on Slavic and foreign music, within its resources and in accordance with the overall mission of the National Theatre; it should also exercise a beneficial influence on national music"]. ${ }^{29}$ Finally, the Theatre was to "usavršavajući muzički repertoar s postepenim prirodnim razvijanjem domaćih snaga" ["improve its musical repertoire by a gradual natural development of domestic forces"] in order to prepare "prve osnove za buduću samostalnu srpsku operu" ["the initial foundations for the future separate Serbian opera"]. ${ }^{30}$ Although this decree underlined a nationally oriented profile of musical performance, the programming policy of the National Theatre with respect to opera was not defined in the Act. At an unspecified point in the future, an opera performing practice, as yet undefined,

\footnotetext{
${ }^{27}$ Cf. Milan Grol, Iz pozorišta predratne Srbije [From Pre-war Serbian Theatres], Belgrade, Srpska književna zadruga, 1939, 48.

${ }^{28}$ Dr Gavrilo Kovijanić, op. cit., 111.

29 Ibid.

30 Ibid.
} 
was meant to find its place at a separate opera institution outside of the National Theatre.

Finally, in 1911, Grol's long-standing policy of obstructing the stage-music life of the National Theatre was finally forced into reverse. The reversal took place owing to the public pressure that followed a performance of the Croatian Royal National Theatre from Zagreb, whose coming to Belgrade was actually Grol's own achievement. As an advocate of international theatre cooperation, which was meant to bring about a modernization of Belgrade's theatre life, Grol spared no effort in promoting the Yugoslav idea through cooperation between South Slavic theatres. It was the practical realization of this idea that induced Grol to make this reversal in his programming policy and finally accept opera as part of the National Theatre's repertoire.

Having resumed his position at the helm of the National Theatre in January 1911, Grol continued his previously arranged theatre cooperation. As a result of this cooperation, the Belgrade tour of the Croatian opera during May and June 1911 brought fifteen performances of ten different works. ${ }^{31}$ Their performances, which were more than successful, raised the question of why Belgrade was musically lagging behind Zagreb and, more broadly, the issue of the quality of opera in Belgrade. "Beograd je bio impresioniran kako repertoarom, tako i izvođačima" ["Belgrade was impressed by the repertoire and performers alike"] ${ }^{32}$ Miloje Milojević, the leading music critic at the time, wrote a highly affirmative review of that performance, published in Srpski književni glasnik. ${ }^{33}$ Public pressure was gradually mounting, demanding from the National Theatre management the establishment of a permanent opera ensemble that could match the theatre from Zagreb.

Istorijsko gostovanje zagrebačke Opere, koje je planirano još za vreme upravnikovanja Milorada Gavrilovića, a ostvareno za vlade Milana Grola, koje će uzbuditi sve duhove, biće prilika i za čitav niz jetkih uvodnika na račun Grola (Novo vreme, Pravda, Večernje novosti....). ... Opersko pitanje postalo je pitanje od prvorazrednog

${ }^{31}$ Cf. Konstantin Vinaver, "Repertoarska politika opere Narodnog pozorišta od njenog osnivanja do danas" ["The Operatic Repertoire Policy of the National Theatre from Its Foundation to the Present"], in: Nadežda Mosusova (ed.), Srpska muzička scena [Serbian Musical Stage], Beograd, Muzikološki institut-Srpska akademija nauka i umetnosti, 1995, 248.

32 Roksanda Pejović, op. cit., 24-25. During the season of 1911-1912 two French theatres and an Italian opera toured in Belgrade. These performances also stimulated debates about the quality of Belgrade's opera life.

${ }^{33}$ Miloje Milojević, "Gostovanje operske trupe Kraljevskog Zemaljskog Hrvatskog Kazališta u Zagrebu" ["The Guest Performance of the Opera Company of the Croatian Royal National Theatre from Zagreb"], Srpski književni glasnik, 1911, 27/1, 62-68 and 1911, 27/2, 134-142. 
značaja, izašlo je čak iz okvira muzike i umetnosti... Postalo je pitanje - nacionalnog prestiža i časti! [The historic visit of the Zagreb Opera, planned while Milorad Gavrilović was still running the Theatre but realized under Milan Grol's administration, a visit that would agitate all spirits, would also serve as an opportunity for a series of caustic editorials at Grol's expense (Novo vreme, Pravda, Večernje novosti....).... The opera question became an issue of paramount importance, even beyond the limits of music and art... It became a question of national prestige and honour. $]^{34}$

Critics felt that "ako se uprava svojim ... nemodernim i jogunastim radom ... ne potrudi da Operu apsorbuje u svoj repertoar, onda bi g. Grol ostao pred Narodnim pozorištem večiti krivac i ništa ga od odgovornosti ne bi spasiti moglo" ["if the management with its ... non-modern and stubborn work ... does not make an effort to absorb opera into its repertoire, then Mr Grol would forever remain a culprit in the eyes of the National Theatre and nothing could save him from that responsibility"']. ${ }^{35}$

After such a public outcry, Grol had no choice but to espouse the cause of opera at the National Theatre. In 1912 he wrote a feasibility study on the modalities of collaboration between South Slavic theatres, in which a prominent place was allotted to the establishing of an art school for the instruction of our actors and singers. ${ }^{36}$ During 1913 and 1914, the opera ensemble of the National Theatre was revived once more and gave a series of performances, with varying success. Nevertheless, Grol's subsequent thoughts reveal that he never became a true supporter of opera at the National Theatre.

Ako se u toj navali velike opere, s velikim horom, baletom, orkestrom, i opremom ima u vidu i veliki dolazak stranih umetnika, taj iznenadni prepad muzike stvorio je takav huk da je drama u pozorištu bila pritešnjena tim nesrazmernim interesom publike za pozorište bez drame. Za Beograđane je velika opera bila veliko zadovoljstvo ali za pozorište velika briga: materijalno, velika briga za organizaciju glomaznog aparata muzike pod istim krovom, velika briga umetnička za uspostavljanje drame iza ratnog poremećaja. [If one bears in mind that this assault of grand opera, with its large choir, ballet, orchestra, and stage design also meant the advent of foreign artists, this surprise attack of music created such an uproar that drama at the theatre was put in a tight spot by such a disproportionate interest of the public for a theatre without

\footnotetext{
${ }^{34}$ Slobodan Turlakov, "Tako se ne piše istorija" ["You Don't Write History like That"], in: Iz muzičke prošlosti Beograda, op. cit., 15.

${ }^{35}$ Anonymous, "Pravac rada Uprave Narodnog pozorišta" ["The Operative Guidelines of the National Theatre Management"], Pravda, 28 March 1910, 1. Quoted. in: Ibid. Slobodan Turlakov points to the fact that "Opera" (with a capital O) refers to Žarko Savić's Opera on the Boulevard.

${ }^{36}$ Cf. Dragana Čolić Biljanovski, op. cit., 65.
} 
drama. For the citizens of Belgrade, grand opera was a grand pleasure, but for the theatre, it was a great concern: materially, a concern in terms of organizing the unwieldy apparatus of music under the same roof; artistically, a concern for reviving drama after the disturbances of war. $]^{37}$

Grol's opinions on the presence of opera at the National Theatre reflected a striking ambivalence in his professional personality, split between that of a politician and a writer. As an Independent Radical, he was in favour of a proEuropean orientation and cultural elitism, with the aim of democratic enlightenment. Advocating an operatic repertoire would not have been inconsistent with such a cultural policy. However, when it came to the life of opera at the National Theatre, Grol abandoned his political guiding principle of following modern European standards. Grol thus reinterpreted his firm political basis in the field of partisan struggles and appropriated the power to regulate the repertoire of the National Theatre; yet, for all that, he never gave up his primary vocation of a writer and dramaturge, who saw the presentation of the highest aesthetic achievements of national and European literature as the sole purpose of the National Theatre in Belgrade.

Translated by Miloš Zatkalik

37 Milan Grol, Iz pozorišta predratne Srbije, op. cit., 259. 